Journal of Engineering and Applied Sciences 15 (3): 847-850, 2020

ISSN: 1816-949X

(C) Medwell Journals, 2020

\title{
Effect of Funding Policy and Working Capital on Financial Performance
}

\author{
Rajindra, Burhanuddin, Rasmi Nur Anggaraeni, Nasrulhak Akkas and Ahmad Yani \\ Universitas Muhammadiyah Palu, Palu, Indonesia
}

\begin{abstract}
This study aimed to analyse the effect of funding policy and working capital on financial performance in Donggala Regency. This study was carried out in 16 districts in Donggala in 2017. The data were analysed using linear regression. The result of the study showed that funding policy and working capital positively and significantly affected the financial performance of micro, small and medium enterprises in Donggala Regency. This study draws result from the impact of funding policy and working capital toward financial performance in micro, small and medium enterprises as previous study did not specifically discuss about this problem.
\end{abstract}

$\underline{\text { Key words: Funding policy, working capital, financial performance, donggala regency, specifically, previous }}$

\section{INTRODUCTION}

Entering the era of the industrial revolution 4.0, the Indonesian government hopes that micro, small and medium enterprises can keep up with technological developments. The development of digitalization, artificial intelligence, internet of things, advanced roboting and crypto currency are among the changes that must be anticipated and followed (Hatammimi and Krisnawati, 2018).

Currently, government policy indicates there is an alignment to accelerate the process of empowering micro, small and medium enterprises. This issue has been determined including providing intellectual and institutional capital. However, to implement this commitment, there are obstacles that are not easily solved only by executive policy.

Despite some policies have been implemented through several new programs in a number of governmental departments and institutions, those programs has not fully empowered the growth acceleration of micro, small and medium enterprises.

The aforementioned problems affected empowerment of micro, small and medium enterprises, thus it is difficult to build an access to the funding sources, lack of working capital, development of human resource quality and development of market and information system (Afrifa et al., 2014).

The empowerment of micro, small and medium enterprises is closely related to the basic conception of micro, small and medium enterprises growth. Designing the basic conception of empowering micro, small and medium enterprises is to build a system that is able to eliminate all problems related to the success of micro, small and medium enterprises. This business aspect is closely related to the capability of the business system that is built which is related to many actors and many variables that have significant and long-term effects (multies years). To find out the condition of each factor and the actors that play a role in it, it is necessary to evaluate it every time, every place and every sector of micro, small and medium enterprises business activities (Tambunan, 2017).

The micro, small and medium enterprises have important roles in developing economy in Donggala because those enterprises can employ quite a number of resources which if exploited proportionally will be able to benefit multiplier effect that can encourage significant regional development in Donggala Regency (Afrifa et al., 2014). These multiplier effect are mostly from the very large number of business units in this unit and its contribution to provide job market (Haron and Nomran, 2016).

This phenomenon is highly correlated to the development of micro, small and medium enterprises periodically in Donggala including lack of funding policy support, lack of working capital which directly affects the weak production capability and comprehensively affects the weak financial performance of micro, small and medium enterprises.

This can be further elaborated by looking at the conditions of micro, small and medium enterprises in Donggala Regency, namely: first, the funding policy is indicated to be still low in internal equity (own capital), so, that some micro, small and medium enterprises still have difficulty in covering costs operations. Second, working capital is still an obstacle in some micro, small and medium enterprises because the working capital owned including cash, trade receivables and inventories is still relatively weak in the aspect of fulfilling cash, there are still often delays in collecting trade receivables 
and slow inventory turnover. Third, the financial performance indicated by profit, investment, assets and sales is still considered low. The Donggala Regency Government has not been optimal in paying attention to the potentially developed micro, small and medium enterprisesnot only in the provision of capital assistance but also in the aspects of funding and working capital policies, so this has not been able to show its performance, especially in the financial aspect. Based on these considerations, this study aimed to analyse the influence of the funding and working capital policy on financial performance in Donggala Regency.

Literature review: Funding policy is a policy that covers the source of funds used to finance an investment that is appropriate. The issue of raising funds is considered important because each fund that will be used must have costs that are often called the cost of funds. When using funds derived from debt, it is clear that the funds have costs which are a minimum of the interest rate but when we use our own capital (equity capital) we also still have to consider the opportunity cost for the intended capital itself. For companies with high sales and profit growth rates, the tendency to use debt as a source of external funds is greater than companies with low sales growth rates (Hatammimi and Krisnawati, 2018; Nthenge and Ringera, 2017). The more stable the sale of a company, the more likely the company covers its activities with debt. Because sales stability will affect income stability, which eventually if the composition of activities of a company is capital intensive, then equity-financing is preferred. This means that loan capital is only a complementary measure, especially to meet the funding needs for working capital. The attitude of management will have a direct influence on policy making on how to meet funding needs. An optimistic manager who looks at his future brightly who has the courage to bear a large risk will be more willing to finance sales growth with funds from debt even though this method of spending with debt provides a permanent financial burden (Nthenge and Ringera, 2017; Yegon et al., 2014).

Companies with a high rate of return tend to use a relatively small proportion of debt, because with a high rate of return the funds needed can be obtained from retained earnings. Some studies show that companies with high return on investment use relatively small debt (Nyabuti and Alala, 2014). In companies, business risk will increase if using high debt. This risk will also increase the possibility of bankruptcy. Business risk is indicated by the variable income received in the future. Companies with high risk should use less debt, to avoid the possibility of bankruptcy. If the manager's goal is to maximize the prosperity/wealth of the shareholders, then the optimal capital structure is one that can maximize the value of the company. Meanwhile, if the manager's goal is to maximize the security of his job, then the optimal capital structure lies in the average leverage of other companies in an industry (Agustina et al., 2019).

\section{MATERIALS AND METHODS}

This study was carried out in 16 districts in Donggala Regency. The data collection was made for secondary and primary data during a 5-month period from January to May 2017 in order to attain accurate data. This study determined the object of the effect of funding policy and working capital toward the financial performance in Donggala Regency which was measured from the actor of micro, small and medium enterprises. The subjects of the study were selected based on entrepreneurs whose business scale is still classified as micro, small and medium scale businesses consisting of types of trading businesses, small industries and service businesses.

The population of the study was all 1752 medium scale entrepreneurs throughout Donggala Regency. Later, sample size was determined using formula by Taro Yamane or Slovin which eventually was distributed proportionally in each district. The sample size was calculated with a $5 \%$ precision $(0.05)$ resulted:

$$
\mathrm{n}=\frac{\mathrm{N}}{\mathrm{N}(\mathrm{di})^{2}+1}=\frac{1752}{1752(0,5)^{2}+1}=326
$$

A number of 326 micro, small and medium enterprise entrepreneurs classified as owners or managers was included into study samples, who generally use loan funds and the production process has been classified as full capacity.

The data were analysed using linear regression, which theoretically the dependent variable (Y) tends to have linear correlation with each independent variable (X). Later, the model was operated using Ordinary Least Square (OLS) in which classical assumptions should be satisfied.

The analysis model was used to analyze the influence of independent variables $\left(\mathrm{X}_{1}\right.$ and $\left.\mathrm{X}_{2}\right)$ on variables $(\mathrm{Y})$. After that the hypothesis of this study was tested using $\mathrm{F}$ and $\mathrm{t}$ test. The model specifications that were the reference in this study were multiple regression formulas for the population:

$$
Y=\beta_{0}+\beta_{1} X_{1}+\beta_{2} X_{2}+\ldots \ldots \ldots \ldots+\beta_{k} X_{k}+\varepsilon_{i}
$$

Where:

Y : Dependent variable

$\beta_{0} \quad$ : Intercept

$\beta_{1} \beta_{k}$ : Partial regression coefficient

$\mathrm{X}_{1} \mathrm{X}_{\mathrm{k}}$ : Independent variables

$\varepsilon_{\mathrm{i}} \quad$ : Epsilon (disturbance's error)

Then the formula was elaborated in the study using the following equation: 
Where:

$$
Y=\beta_{0}+\beta_{1} X_{1}+\beta_{2} X_{2}+\varepsilon_{i}
$$

$\mathrm{Y} \quad$ : Financial performance

$\beta_{0}:$ Intercept

$\beta_{1} \beta_{2}$ : Partial regression coefficient

$\mathrm{X}_{1}$ : Funding policy

$\mathrm{X}_{2}$ : Working capital

$\varepsilon_{\mathrm{i}} \quad$ : Epsilon (disturbance’s error)

\section{RESULTS AND DISCUSSION}

The result of the study can be determined through Variance Inflating Factor (VIF), if the value of the variance inflating factor with a tolerance number is close to 1 , the presented data does not occur multicollinearity. From the results of data analysis, it shows that the variables analyzed by the inflating value of factors and their tolerance numbers show no multicollinearity with a VIF value of 1.000 , the cut-off value used to indicate multicollinearity is: if the tolerance value is $<0.10$; then multicollinearity occurs but if the tolerance value is $>0.10$; then there is no multicollinearity. The data analysis showed that both funding policy (X1) and working capital variables had tolerance value of 0.754 and VIF was 1.327. The multicollinearitytest showed that no correlation found between independent variables, tolerance value $>0.10$ and thus no multicollinearityoccurred (Table 1).

To test the variance from multiple regression used to explain independent and dependent variables by testing the significance of its regression coefficient. The regression coefficient of regression modelis explained in Table 2. As shown in Table 2, we acquired the following regression equation:

$$
\mathrm{Y}=1.375+0.315\left(\mathrm{X}_{1}\right)+0.134\left(\mathrm{X}_{2}\right)
$$

In the multiple linear regression model equation, the regression coefficient value of the independent variable (X) was obtained, namely the funding policy (X1) and working capital (X2) had a positive effect, the positive coefficient value of the independent variable means that if there is a change in the independent variable (X), it will cause a direct change in the dependent variable (Y), i.e., financial performance and vice versa. In other words, the financial performance variable $(\mathrm{Y})=1.375$ if there is no influence of the funding policy variable (X1) and working capital (X2) or equal to 0 (zero) while the financial performance variable $(\mathrm{Y})$ will increase by 1.375 from a constant value of 1.375 if there has been an increase of 1 value in the funding policy variable (X1) and working capital (X2).

The correlation coefficient value of 0.622 shows a moderate correlation between between funding policy (X1) and working capital (X2) toward the financial performance (Y) with coefficient interval of 0.60-0.699. Likewise, the R square (coefficient of determination) was 0.387 means $38.7 \%$ of financial performance was determined by funding policy (X1) and working capital (X2) and therefore $61.3 \%$ was explained by other variables which are not identified in this study, that is production capability, marketing communication, business partnership, product enrichment and work productivity.

This shows that the funding and working capital policies together affect the financial performance in Donggala Regency. Companies basically always need capital, both working capital and fixed capital. Working capital is very important for smooth operations and for other interests that are short-term because this working capital will always rotate as long as the company is in a business condition and working capital can be used to maintain company performance.

Working capital management is usually intended as an arrangement of current assets, namely cash, securities, receivables and inventories and current or short-term debt management. Current assets show the amount of money they have and assets that have been converted into money. It is often said that each asset has a different level of liquidity. Cash itself is the most liquid asset. As for other assets, liquidity has two dimensions, namely the time required to turn into cash and the level of certainty associated with the ratio of change or the price of the asset. The amount of investment in current assets will affect the value of the company. While the funding policy is the company's ability to pay obligations in the future or

Table 1: The multicollinearity test

\begin{tabular}{lll}
\hline & Collinearity statistics & \\
Independent variables & Tolerance & VIF \\
\hline Funding policy (X1) & 0.754 & 1.327 \\
Working capital (X2) & 0.754 & 1.327 \\
\hline
\end{tabular}

Table 2: The result of multiple regression

\begin{tabular}{|c|c|c|c|c|c|c|}
\hline \multirow[b]{2}{*}{ Variables } & & & & \\
\hline & Reg. coeff & Std. error & Beta & t-count & t-table & Sig \\
\hline $\mathrm{C}=$ Constanta & 1.375 & 0.170 & & 8.078 & & 0.000 \\
\hline X1 = funding policy & 0.315 & 0.038 & 0.411 & 8.195 & 1.970 & 0.000 \\
\hline X2 = working capital & 0.314 & 0.052 & 0.305 & 6.085 & 1.970 & 0.000 \\
\hline \multicolumn{7}{|c|}{$\mathrm{R}=0.622 \mathrm{~F}$ statistic $=101,996$} \\
\hline \multicolumn{7}{|c|}{$\mathrm{R}^{2}=0.387$ Sig. $\mathrm{F}=0.000$} \\
\hline \multicolumn{7}{|c|}{ Adjusted $\mathrm{R}^{2}=0.383 \mathrm{~F}$-table $=3.36$} \\
\hline Durbin-Waston $=1.549$ & & & & & & \\
\hline
\end{tabular}

Dependent variable $\mathrm{Y}$ = financial performance 
a low business risk, it will be responded positively by the market. There are two views regarding funding decisions. The first view is known as the traditional view which states that the capital structure affects the value of the company (Khabirov et al., 2019).

The second view of the policy that must be considered in optimizing the value of the company is a dividend policy where investors have the main objective to improve welfare by expecting returns in the form of dividends and capital gains while the company expects continuous growth to maintain its survival while at the same time providing welfare to its shareholders, so, the dividend policy is important to meet the expectations of shareholders towards dividends by not hampering the company's growth on the other hand (Agustina et al., 2019).

The result of this study reveals that funding policy and working capital variables had simultan and significant effect on financial performance in Donggala Regency. Furthermore, this result is supported by theory related to funding policy, traditionally the first category in performance measures is analysis of future cash flow starting with profitability analysis. Theoretically, effective and efficient working capital management will greatly affect the company's financial position, especially will improve the company's financial performance (Murphy and Bernier, 2011). Management of working capital needs has a very close relationship.

\section{CONCLUSION}

This study concludes that funding and working capital policies have a positive and significant impact on financial performance in micro, small and medium enterprises in Donggala Regency. This study recommends that micro, small and medium enterprises entrepreneurs should consider the use of retained earnings in addition to meeting working capital needs, operational costs, purchasing production equipment and should also be directed to anticipate the emergence of unexpected costs.

\section{REFERENCES}

Afrifa, G.A., V. Tauringana and I. Tingbani, 2014. Working capital management and performance of listed SMEs. J. Small Bus. Entrepreneurship, 27: 557-578.
Agustina, I.L., E. Fauziv, A. Anwar, H.S. Ogalo and I. Ratnasari, 2019. The role of financial management in bringing efficiency in supply chain management. Int. J. Supply Chain Manage., Vol. 8,

Haron, R. and N.M. Nomran, 2016. Determinants of working capital management before, during and after the global financial crisis of 2008: Evidence from Malaysia. J. Dev. Areas, 50: 461-468.

Hatammimi, J. and A. Krisnawati, 2018. Financial literacy for entrepreneur in the industry 4.0 era: A conceptual framework in Indonesia. Proceedings of the 2018 10th International Conference on Information Management and Engineering (ICIME'18), September 22-24, 2018, ACM, Salford, UK., pp: 183-187.

Khabirov, G.A., Z.Z. Suleymanov, A.M. Ableeva, G.A. Salimova and E.I. Galimova, 2019. The application of international financial reporting standards in the dairy horse breeding in supply chain management. Int. J. Supply Chain Manage., 8: 266-274.

Murphy, E.V. and M.B. Bernier, 2011. Financial stability oversight council: A framework to mitigate systemic risk. Congressional Research Service, Washington, DC., USA. https://www.llsdc.org/assets/Dodd Frankdocs/crs-r42083.pdf

Nthenge, D. and J. Ringera, 2017. Effect of financial management practices on financial performance of small and medium enterprises in Kiambu Town, Kenya. Am. Based Res. J., Vol. 6, No. 1.

Nyabuti, W.M. and O.B. Alala, 2014. The relationship between working capital management policy and financial performance of companies quoted at Nairobi Securities Exchange, Kenya. Int. J. Econ. Finance Manage. Sci., 2: 212-219.

Tambunan, T.T.H., 2017. MSMEs and Access to Financing in a Developing Economy: The Indonesian Experience. In: Financial Entrepreneurship for Economic Growth in Emerging Nations, Woldie, A. and B. Thomas (Eds.). IGI Global, Pennsylvania, USA., ISBN-13: 978-1522527008, pp: 148-172.

Yegon, C.K., K.J. Kiprono and C. Willy, 2014. Working capital management and corporate financial performance: Evidence from panel data analysis of selected quoted tea companies in Kenya. Res. J. Finance Accounting, 5: 53-62. 